\title{
Relationship between C677T Methylenetetrahydrofolate Reductase Gene Polymorphism and Homocysteine in Cerebral Palsy
}

\author{
Uni Gamayani, ${ }^{1}$ M. Hasan Machfoed, ${ }^{2}$ Ponpon Idjradinata, ${ }^{3}$ Tri Hanggono Achmad ${ }^{4}$

\begin{abstract}
${ }^{1}$ Department of Neurology, Faculty of Medicine, Universitas Padjadjaran-Dr. Hasan Sadikin General Hospital ${ }^{2}$ Department of Neurology, Faculty of Medicine, Airlangga University-Dr. Soetomo General Hospital ${ }^{3}$ Department of Child Health, Faculty of Medicine, Universitas Padjadjaran-Dr. Hasan Sadikin General Hospital ${ }^{4}$ Department of Biochemistry and Cell Biology, Faculty of Medicine, Universitas Padjadjaran
\end{abstract}

\begin{abstract}
Objective: To observe the relationship between methylenetetrahydrofolate reductase (MTHFR) C677T gene polymorphism and homocysteine levels in cerebral palsy (CP) children.

Methods: This cross-sectional study was conducted in several hospitals, school for children with special needs, and rehabilitation centers in Bandung from March to November 2014, on children with CP aged 4-14 years who met the inclusion criteria. Genotyping was performed using polymerase chain reaction (PCR)-restriction fragment length polymorphism (RFLP) and direct sequencing. Homocysteine serum level was measured using chemiluminescent microparticle immunoassay (CMIA) method. Statistical analysis was conducted using t test.
\end{abstract}

Results: In this study, 150 CP children had MTHFR C677T gene polymorphism with a frequency of $18 \%$, consisting of TT homozygotes (4\%), CT heterozygotes (14\%), and T allele (11\%. The mean serum level of homocysteine in CP with C677T MTHFR gene polymorphism was $8.22( \pm 1.89) \mu \mathrm{mol} / \mathrm{L}$, higher than those without polymorphism ( $\mathrm{p}=0.046)$.

Received: Conclusions: A relationship between MTHFR C677T gene polymorphism December 29, 2015 and homocysteine level in children with cerebral palsy is found in this study.

Revised:

March 3, 2016

Keywords: Cerebral palsy, homocysteine, methylenetetrahydrofolate

Accepted:

March 9, $2016 \quad$ IJIHS. 2016;4(1):20-5

\section{Introduction}

Cerebral palsy (CP) is a neurodevelopmental disorder that is most frequently found and one of the main causes of physical disability in children. The worldwide prevalence of CP is 2-3/1000 live births. ${ }^{1}$ In Indonesia there are currently no data on the prevalence of CP.

$\mathrm{CP}$ is a disease with multifactorial causes; $70-80 \%$ of all cases occur during the prenatal period and the rest of the cases occur during perinatal or postnatal period. It is currently considered that genetic disorders play an important role in the occurrence of CP. These

\footnotetext{
Correspondence:

Uni Gamayani, Department of Neurology, Faculty of Medicine, Universitas Padjadjaran-Dr. Hasan Sadikin General Hospital

Jl. Pasteur No. 38, Bandung, Indonesia

e-mail: gamayani@yahoo.com
}

genetic disorders are also found in some other developmental disorders, such as intelligence disorders and autism spectrum disorders. ${ }^{2,3} \mathrm{~A}$ number of studies were conducted to support this statement, such as studies on CP-related genes as well as studies on the presence of single nucleotide polymorphisms (SNPs). ${ }^{4,5}$ In this respect, Callaghan et al. ${ }^{6}$ had conducted a systematic literature review and discovered that there were approximately 22 studies related to the relationship of SNPs and CP. One of the candidate genes in this relation with $\mathrm{CP}$ is methylenetetrahydrofolate reductase (MTHFR). However, results of studies on the relationship between $\mathrm{CP}$ and genetic factors were still unsatisfactory due to the limitation in subjects, ethnic differences, and inadequate control. A study conducted in China reported that there is a significant relationship between MTHFR C677T gene polymorphism and CP 
accompanied by severe mental retardation. ${ }^{7}$

Human MTHFR is encoded by the MTHFR gene. This enzyme plays an important role in the metabolism of folate and homocysteine. In the homozygous state there is a decrease in enzyme functions up to $60 \%$. Meanwhile, in heterozygotes, the decrease is only about $30 \%$. MTHFR C677T polymorphism gene may alter folate metabolism and low folate intake may result in increased levels of homocysteine. This may lead to a decrease in DNA methylation at the cellular level and, eventually, neuronal cell damage and death. Methylation is involved in almost all reactions in the body and is very important for the biomolecular reaction processes. ${ }^{8}$ It is already widely known that methylenetetrahydrofolate reductase, which is an enzyme, possesses the ability to convert the 5.10 methylentetrahydrofolate into 5 methyltetrahydrofolate, the main form of folate in the circulation. 5 methyltetrahydrofolate is used in a process to convert homocysteine to methionine. Furthermore, methionine is converted to S-adenosylmethionine (SAM). $\mathrm{S}$-adenosylmethionine is a major methyl donor in methylation processes which also functions in transmethylation of phospholipids, myelin, choline, and catecholamine. Reduced MTHFR enzyme activity may lead to a decrease in the production of tetrahydrofolate required for DNA synthesis and adenosyl methionine, which is necessary for DNA methylation. Increased homocysteine can cause oxidative stress; lower transcription and translation; and reduced enzyme-catalysed activity of glutathione peroxidase (GPx) and superoxide dysmutase (SOD)..$^{8-9}$ In contrast, increased level of homocysteine can increase neurotoxicity by inducing apoptosis of neurons and by adding excitotoxicity which leads to DNA damage, activation of poly- ADP-ribose polymerase (PARP), and induction of p53.9 The action of MTHFR enzyme is influenced by vitamin B as a co-factor as well as by important enzymes like cysthationine beta synthase and methionine synthase. ${ }^{8}$

Increased homocysteine level with MTHFR C677T gene polymorphism contributes to the brain damage found in CP. The aim of this study was to prove the association between C677T MTHFR gene polymorphism and serum homocysteine levels in CP children in Bandung.

\section{Methods}

Subjects of the study were CP patients at the Child Neurology Clinic of Al Islam Hospital,
Borromeus Hospital, Melinda Hospital, some rehabilitation centers for children with special needs, and special schools for children with disability in Bandung and its surrounding areas who met the inclusion and exclusion criteria of the study. Subject collection was conducted in the period of March to November 2014.

This study was a comparative analytical study with cross-sectional methods. Sampling was performed with consecutive admission sampling method. The objective of this study was to find the relationship between C677T MTHFR gene polymorphism and the level of serum homocysteine in CP children. Before data collection, informed consent was obtained from the parents of these CP children.

Inclusion criteria for this study were children diagnosed as having spastic cerebral palsy with hemiplegia, diplegia, and tetraplegia; aged 4-14 years old; and degree of Gross Motor Function Classification System (GMFCS) I and II. Exclusion criteria were the clinical presence of any signs of major congenital anomalies that lead to certain syndromes (Down's syndrome, Tuberosclerosis syndrome, Sturge Weber syndrome, Neurofibromatosis syndrome, and Fragile X), autism spectrum disorders, and abnormalities of brain degeneration.

MTHFR C677T gene polymorphisms were identified through the isolation from peripheral blood sample. The extracted genomic DNA samples then underwent Polymerase Chain Reaction (PCR) - Restriction Fragment Length Polymorphism (RFLP) and, later, sequencing. Determination of MTHFR gene polymorphism. This process was conducted at the molecular genetic laboratory of the Faculty of Medicine, Universitas Padjadjaran. Homocysteine serum level was measured using Chemiluminescent Microparticle Immunoassay method (CMIA) at the clinical pathology laboratory of Dr. Hasan Sadikin General Hospital Bandung. The relationship between the MTHFR gene C677T polymorphism and serum homocysteine levels was analyzed statistically using $\mathrm{T}$ test with a significance level of $p<0.05$.

This study has received ethical approval from the Health Research Ethics Committee, Faculty of Medicine, Universitas Padjadjaran.

\section{Results}

During the study period, 150 children with cerebral palsy were enrolled. The mean homocystein serum level was $7.60( \pm 1.88)$ $\mu \mathrm{m} / \mathrm{L}$. The characteristics of subjects were 
shown (Table 1).

The distribution of allele and genotype frequency of the MTHFR gene were shown (Table 2). From this data, it appears that the frequency of C677T polymorphism that is $\mathrm{T}$ allelic is $11 \%$. Genotyping results showed that 27 (18\%) subjects experienced polymorphism.

The mean homocysteinelevels in CP patients with C677T MTHFR gene polymorphism was higher when compared to those without C677T MTHFR gene polymorphism (Table 3 ). This difference was statistically significant $(\mathrm{p}=0.046)$.

\section{Discussion}

In this study, the frequency of the MTHFR gene C677T polymorphism was $18 \%$, consisting of CT genotype (14\%), TT genotype (4\%), and $\mathrm{T}$ allele frequency $(11 \%)$. This is in line with the results of a study in normal population of Bandung by Widjajakusumah ${ }^{10}$ in 2004, which presented a CT genotype frequency of $17 \%$ and a $\mathrm{T}$ allele frequency of $10 \%$. A similar result was also presented in a study by Primasari ${ }^{11}$ in 2013 showing a CT genotype frequency of $21.2 \%$, TT of $0 \%$ and T allele frequency of $10.6 \%$. A study in Malaysia in 2012 showed that the frequency of the MTHFR C677T gene polymorphism in the general population was $17.5 \% .^{12}$

\section{Table 1 Subject Characteristics}

\begin{tabular}{lcc}
\hline \multicolumn{1}{c}{ Characteristics } & $\mathbf{n = 1 5 0}$ \\
\hline Age (month) & $115.67(35.75)$ \\
Mean (SD) & 120 \\
Median & $48-168$ \\
Range & & \\
Sex & 93 & $(62 \%)$ \\
Male & 57 & $(38 \%)$ \\
Female & & \\
Cerebral palsy type & 11 & $(7.3 \%)$ \\
Hemiplegic & 133 & $(88.7 \%)$ \\
Tetraplegic & 6 & $(4.0 \%)$ \\
Diplegic & & \\
GMFCS type & 42 & $(28 \%)$ \\
GMFCS I & 108 & $(72 \%)$ \\
GMFCS II & &
\end{tabular}

Table 2 Allele Frequency and Genotype Distribution of the MTHFR C677T Gene Polymorphism in Cerebral Palsy

\begin{tabular}{cc}
\hline \multicolumn{1}{c}{ Variable } & Frequency n(\%) \\
\hline Allele & \\
C & $267(89)$ \\
T & $33(11)$ \\
Genotype & \\
CC & $123(82)$ \\
CT & $21(14)$ \\
TT & $6(4)$ \\
\hline
\end{tabular}

Studies on the presence of MTHFR C677T gene polymorphism in the incidence of $\mathrm{CP}$ has been conducted in several countries with different results. A study in Australia on 349 patients with cerebral palsy showed that MTHFR C677T gene polymorphism occurred at $61.03 \%$, while in the control group, the occurence was $57.60 \%$. It was concluded that MTHFR C677T gene polymorphism is not a risk factor for CP. ${ }^{13}$

Research on Jewish and Arabic subjects in Israel in 2005 showed that the prevalence of the MTHFR C677T gene polymorphism in CP was $15 \%$ compared to the prevalence in the control group of $13 \% .{ }^{14}$ The different ethnicity of the subjects might be one of the causative possibilities. ${ }^{6}$

Until today, this is the first study on C677T polymorphism in the MTHFR gene with CP in Bandung. Research in Asia on the MTHFR gene polymorphism in CP has been performed in China, with the results showing MTHFR C677T gene polymorphism frequencies of $44.4 \%$ for CC, $44.4 \%$ for CT and $12.6 \%$ for TT. Meanwhile, CP that was accompanied by mental retardation has the frequencies of $34.9 \%$ for CC, $48.8 \%$ for CT and $16.3 \%$ for TT. ${ }^{7}$ Compared to other studies, it appears that the genotype frequency of the MTHFR C677T gene polymorphism in patients with cerebral palsy in Bandung was smaller compared to these studies in China and Australia.,13 However, compared to the studies in Israel, the frequency of the MTHFR C677T gene polymorphism in this study is greater. ${ }^{14}$

The homocysteine level criteria in normal adults that is commonly used is $5-15 \mu \mathrm{mol} / \mathrm{L}$. Widjajakusumah ${ }^{10}$ had conducted a study in Bandung and found that the homocysteine levels in normal adult is $9-10 \mu \mathrm{mol} / \mathrm{L}$, regardless of the gender. Homocysteine levels 
Table 3 Comparison of Homocysteine Levels in Cerebral Palsy with and without MTHFR C677T Gene Polymorphisms

\begin{tabular}{lccc}
\hline \multirow{2}{*}{ Variable } & \multicolumn{2}{c}{ Cerebral Palsy } & \\
\cline { 2 - 3 } & $\begin{array}{c}\text { Polymorphism }(+) \\
\mathbf{n = 2 7}\end{array}$ & $\begin{array}{c}\text { Polymorphism } \\
(-)\end{array}$ & p value \\
& & & 0.046 \\
Homocysteine level $(\boldsymbol{\mu m o l} / \mathrm{L})$ & $82.2(1,89)$ & $7.46(1,88)$ & \\
Mean (SD) & 7.91 & 7.46 & \\
Median & $5.70-13.77$ & $3.94-12.70$ & \\
Range & &
\end{tabular}

in normal children from several studies were compared. A study in Norway mentioned that the homocysteine levels in normal prepuberty children aged less than 15 years old was 4-8 $\mu \mathrm{mol} / \mathrm{L}^{15}$ In these prepuberty children, homocysteine levels are not influenced both by age and hormones. The levels of homocysteine can be affected by age, kidney function, muscle mass, vitamin status, and genetics. In addition, homocysteine levels are also affected by proliferative disease, hypothyroidism, several drugs including methotrexate, anti-epileptic drugs, L-dopa antagonist, folic acid, and vitamin B12. This study concludes that both in children and adolescence, homocysteine levels are influenced by ethnicity, of which plasma concentration of homocysteine in black people are higher than whites or Hispanics. ${ }^{15}$

Another study which was conducted by Kumari et al. ${ }^{16}$ in East India, which is an area of folate and vitamin B12 deficiencies, showed that the average homocysteine levels in normal male children were 13.2 (9.7 to 16.7) $\mu \mathrm{mol} / \mathrm{L}$ while in female children the levels were 11.7 (7.7 to 16$) \mu \mathrm{mol} / \mathrm{L}$. In a study conducted by Sirachainan et al.17 in 2008 in normal children in Thailand, the mean homocysteine level was $11 \mu \mathrm{mol} / \mathrm{L}$. A study in Manado, Indonesia, found that normal children aged 7-8 years has the average homocysteine level of 5.28 $( \pm 0.655) \mu \mathrm{mol} / \mathrm{L}^{18}$

From these studies, it is apparent that there are different normal levels of homocysteine in children with different ethnicities. The different diets of these children, according to their respective ethnicity, might be one causative possibility. ${ }^{17}$

In this study, the mean homocysteine level in CP of $7.60( \pm 1.88) \mu \mathrm{mol} / \mathrm{L}$ was lower than in other studies, except when this data compared to the average levels of homocysteine in normal children in Manado, with a higher level of homocysteine. Nutritional factors, e.g. inadequate vitamin intake and genetic factors; comorbidities, e.g. renal disorders, thyroid dysfunction; and drug consumptions can lead to these differences in the levels of homocysteine. ${ }^{15}$

One possible cause of elevated levels of homocysteine is a defect in the MTHFR gene. The presence of polymorphisms in this gene defect may lead to reduced MTHFR enzyme activity. Homocysteine metabolism in the body is influenced by the deficiency of folic acid as a substrate, vitamin B6 and B12 as co-factors, and defect in the gene encoding the enzyme in the homocysteine metabolism, such as the MTHFR enzyme, cystathionine beta-synthase, and methionine synthase. ${ }^{8}$

In the present study, the mean levels of homocysteine in CP with MTHFR C677T gene polymorphism was $8.22( \pm 1.89) \mu \mathrm{mol} / \mathrm{L}$. Meanwhile, the mean homocysteine levels in $\mathrm{CP}$ without polymorphism was $7.46( \pm 1.88)$ $\mu \mathrm{mol} / \mathrm{L}$, meaning that the difference is significant. In a study conducted by Bottiger in Sweden in 2006, homocysteine levels in normal children aged 9-10 years and 15-16 years were associated with the MTHFR C677T gene polymorphism. The results showed that in children aged 9-10 years the average level of homocysteine in the CC genotype was 6.28 $( \pm 1.14) \mu \mathrm{mol} / \mathrm{L}$, genotype CT $6.60( \pm 1.40)$ $\mu \mathrm{mol} / \mathrm{L}$, the TT genotype $7.36( \pm 1.57) \mu \mathrm{mol} / \mathrm{L}$. There were no significant differences between age and sex. Whereas in children aged 15-16 years, the average levels of homocysteine in the MTHFR C677T gene polymorphism with CC genotype was $8.28( \pm 1.72)$, CT was 8.98 $( \pm 2.85)$, and TT was $18.63( \pm 14.34) \mu \mathrm{mol} / \mathrm{L}$. 
Hence, significant differences between gender and age were found in this group. ${ }^{19}$

The mean level of homocysteine in $\mathrm{CP}$ with the MTHFR C677T gene polymorphism in this present study is higher compared to that of the Swedish study. The same is true for the mean homocysteine level in CP without C677T MTHFR gene polymorphism.

Different dietary patterns of Indonesian children when compared to children in Europe and elsewhere may be the reason for these differences, since in European countries folic acid fortification in children is a common practice.

Levels of homocysteine in CP group with gene polymorphism were higher than that of the normal children. This is in accordance with the literatures which state that the presence of a defect in the MTHFR gene causes increased homocysteine level. Another speculation regarding the factor that contributes to this increase is the inadequate vitamin B status of the subject. Vitamin B acts as a cofactor of the enzyme in the metabolism of homocysteine. Since the given levels of homocysteine in CP without MTHFR C677T gene polymorphism is also relatively high, the possibility of low vitamin B status on all subjects and the presence of genetic disorders that affect homocysteine should be evaluated. ${ }^{9}$ In conclusion, there is a relationship between MTHFR C677T gene polymorphism and homocysteine level in children with cerebral palsy.

\section{References}

1. Pennington L, Virella D, Mjoen T, Da Graca AM, Murray J, Colver A, et al. Development of The Viking Speech Scale to classify the speech of children with cerebral palsy. Res Dev Disabil. 2013;34(2013):3202-10.

2. Bokhoven H. Genetic and epigenetic networks in intellectual disabilities. Annu Rev Genet 2011;45:81-104.

3. Miles JH. Autism spectrum disorders--a genetics review. Genet Med. 2011;13(4):27894.

4. Moreno-De-Luca A, Helmers SL, Mao H, Burns TG, Melton AM, Schmidt KR, et al. Adaptor protein complex-4 (AP-4) deficiency causes a novel autosomal recessive cerebral palsy syndrome with microcephaly and intellectual disability. J Med Genet. 2011;48(2):141-4.

5. Abou Jamra R, Philippe 0, Raas-Rothschild A, Eck SH, Graf E, Buchert R, et al. Adaptor protein complex 4 deficiency causes severe autosomalrecessive intellectual disability, progressive spastic paraplegia, shy character, and short stature. Am J Hum Genet. 2011;88(6):788-95.

6. O'Callaghan ME, MacLennan AH, Haan EA, Dekker G; South Australian Cerebral Palsy Research Group. The genomic basis of cerebral palsy: a HuGE systematic literature review. Hum Genet. 2009;126(1):149-72.

7. Cheng X, Li T, Zhu D, Ma C, Ma B, Wang Y, et al. Methylenetetrahydrofolate reductase gene polymorphism and cerebral palsy in Chinese infants. J Human Gen. 2011;56(1):17-21.

8. Leclerc D, Sibani S, Rozen R. Molecular biology

of Methylenetetrahydrofolate reductase (MTHFR) and overview of Mutation/ Polymorphism. Madame Cury Bioscience Database Landes Bioscience. 2000.

9. Handy DE, Zhang, Loscalzo J. Homocysteine downregulates cellular glutathione peroxidase (GPx1) by decreasing translation. J Biol Chem. 2005;280(16):15518-25.

10. Widjajakusumah B, Peran mutasi gen metilentetrahidrofolatreduktase (MTHFR) 677C $\rightarrow \mathrm{T}$ kadar homosistein plasma dan kadarfolat plasma dalam terjadinya sindrom koroner akut [dissertation]. Bandung: Universitas Padjadjaran; 2004.

11. Primasari A. Asosiasi polimorfisme gen metilentetrahidrofolatreduktase maternal dan gen transforming growth factor alpha serta pengaruh faktor lingkungan pada celah bibir non sindromik [dissertation]. Bandung: Universitas Padjadjaran; 2008.

12. Liew SC, Gupta ED, Wong SF, Lee $\mathrm{N}$, Safdar N, Jamil A. Association of MethylentetrahydrofolateReductas (MTHFR) 677C $\rightarrow$ T gene polymorphism and homocysteine level in psoriasis vulgaris patients from Malaysia : a case control study. Nutr J. 2012;11(1):44-8.

13. Gibson CS, MaclennanAH, Dekker GA, Goldwater PN, Sullivan TR, Munroe DJ, et al. Candidate genes and cerebral palsy: a population-based study. Pediatrics. 2008;122(5):1079-85.

14. Yehezkely-Schildkraut V, Kutai M, Hugeirat Y, Levin C, Shalev SA, Mazor G, et al. 
Thrombophilia: a risk factor for cerebral palsy? Isr Med Assoc J. 2005;7(12):808-11.

15. MBjørke Monsen AL, Ueland PM. Homoysteine and mrthylmalonic acid in diagnosis and risk assessment from infancy to adolescence. Am J Clin Nutr. 2003;78(1):7-21.

16. Kumari P, Ali A, Sukla KK, Singh S. Raman R. Lower incidence of non syndromic cleft lip with or without cleft palate in females. Is homocysteine a factor? J Biosci. 2013;38(1):216.

17. Sirachainan N, Sasanakul W, Visudtibhan A, Tapanapruksakul P, Charuenkwan P, Kadesgasem, et al.The effect of polymorphisms of MTHFR C677T, A1298C, MS A2756G and CBS 844ins68BP on plasa total homocysteine level and the risk of ischemic stroke in Thai children. Thromb Res. 2008;122(1):33-7.

18. Louis IM, Umboh A. Plasma homocysteine and blood pressue in small gestational age children. Pediatr Indones. 2013;53(5):254-7.

19. Böttiger AK, Hurtig-Wennlöf A, Sjöström $M$, Yngve A, Nilsson TK. Association of total plasma homocysteine with methylenetetrahydrofolate reductase genotypes $677 \mathrm{C}>\mathrm{T}, 1298 \mathrm{~A}>\mathrm{C}$, and $1793 \mathrm{G}>\mathrm{A}$ and the corresponding haplotypes in Swedish children and adolescents. Int J Mol Med. 2007;19(4):659-65. 